\title{
Judit Nényei
}

\section{The Dancer as Femme Fatale}

\author{
in Arthur Symons, W. B. Yeats and James Joyce
}

Arthur Symons describes the dancer as "the intellectual as well as sensuous appeal of a living symbol [...] ber gesture, all pure symbol."1 It is worth considering why it is so obvious that the dancer must be female. The origin of the dancer, as essentially female, does not come from Symons: it was Mallarmé who first described the dancer as "une femme qui danse." 2 Although both sexes were equally represented in ballet when it had become fashionable during the eighteenth century, gradually fewer and fewer men took part in it. Ballet had developed as an extremely refined, graceful art, and the robust, muscular male body did not suggest this ethereal beauty and refinement. Ballet offered a double chance to the imagination of the audience: an escape from reality into this artificial world of light, seemingly easy and effortless movements, where verbal communication ceases and gestures acquire communicative value; as Symons wrote: "I go to see a ballet in order to get as far as possible from the intolerable reality of the world around me." 3 Furthermore, the ballet dancer appeared, for many, as an unreachable, mysterious, self-sufficient being, inhuman, yet somehow the realisation of the desire of ordinary people, who were sitting in the audience. While dancing, she seemed to express an enigmatic knowledge of the supernatural world, to which she, while the dance lasted, appeared to belong; an extraordinary aura surrounded her. The popularity of many ballerinas can be explained by the cathartic sensations they awoke in

\footnotetext{
1 Arthur Symons, Studies in Seven Arts (London: Martin Secker, 1906), p. 246.

2 Stéphane Mallarmé, "Crayonné au Théâtre" in Oeuvres Complétes(Taris: Librairie Gallimard, 1945), p. 304, quoted by Sylvia C. Ellis, The Plays of W. B. Yeats: Yeats and the Dancer (London: Macmillan, 1995), p. 6.

3 Sketch, 7 August 1895, p. 14.
} 
the members of the audience: after the performance the admirers sought the secret of this enigma, but it only revealed itself during the dance. Fither the proud selfsufficiency, or the suggested lack of passion of the dancer, offered a challenge to conquer and/or awake passion in the apparently "ice and diamond" ballerinas.

Apart from ballet, there was a plethora of dancers who introduced different principles in dancing. "Free" dancers, interpretative dancers, skirt dancers, Oriental (authentic or 'imitative') dancers flooded the theatre stages, vaudevilles and music halls of Europe. Arthur Symons dedicated several poems to them, and these poems indicate the variety of the performers. The exotic dancers, for instance, could always find an audience: their popularity was ensured by the expectant atmosphere of romanticism and decadence that prevailed the era. Symons found inspiration in Javanese,${ }^{4}$ Indian and Armenian dancers, and as Yeats recalled, Loië Fuller's ${ }^{5}$ Japanese dancers but mistook them for Chinese. Thus it was not really the authentic nationality of the dancer that mattered but her exotic and exciting performance, and even more the subjective emotions, thoughts and desires they evoked in the poet. A characteristic poem in Symons's auvr: "To a Gitana Dancing" (1899) stresses the elimination of time while the dance lasts, the spell that the dancer casts upon her audience, and the dream-like state they experience during her performance:

And the maze you tread is as old as the world is old, Therefore you hold me, body and soul, in your hold, And time, as you dance, is not, and the world is as nought. You dance, and I know the desire of all flesh, and the pain Of all longing of body for body; you beckon, repel, Entreat, and entice, and bewilder, and build up the spell, Link by link, with deliberate steps, of a flower-soft chain.

You pause: I awake; have I dreamt? was it longer ago Than a dream that I saw you smile? for you turn, you turn, As a startled beast in the toils: it is you that entreat, Desperate, hating the coils that have fastened your feet, longing has taken hold even on you, You, the witch of desire; and you pause, and anew Your stillness moves, and you pause, and your hands move. Time, as you dance, is as nought, and the moments seem

\footnotetext{
4 Arthur Symons, "Javanese Dancers" quoted by Frank Kermode, Romantic Image (Iondon: Routledge \& K. Paul, 1957), p. 70.

${ }^{5}$ Loië Fuller, Fifteen Years of a Dancer's Life (New York: Dance Horizons, 1913).
} 
Swift as eternity; time is at end, for you close eyes and lips and hands in sudden repose;

You smile: was it all no longer ago than a dream?"

Yeats wrote his Rosa.Alchemica (1897), ${ }^{7}$ which cxhibits similar features to this poem and which I shall discuss later in this essay, almost at the same time. Symons's "The Armenian Dancer" (1906) also demonstrates the influence the dancers had over their audience, and at the same time serves as an interesting example for such expressions and ideas of describing the dancer's movements, that could be encountered in the plays and poems of Yeats and some of the early works of Joyce. Certain passages of this short poem might illustrate my argument:

O secret and sharp sting

That ends and makes delight

Come, my limbs call thee, smite

To music every string

Of my limbs quivering.

I dance, and as I dance

Desires as fires burn white

To fan the flame delight;

What vague desires advance

With covered countenance?

The sense within me turns

In labyrinths as of light,

Not dying into delight;

As a flame quickening burns,

Speed in my body yearns.

I stop, a quivering

Wraps me and folds me tight;

I shudder, and touch delight,

The secret and sharp sting,

Suddenly, a grave thing. ${ }^{8}$

${ }^{6}$ Arthur Symons, Images of Good and Evil (London: Heinemann, 1899), pp. 107-9.

${ }^{7}$ W. B. Yeats, The Secret Rose (London: Lawrence \& Builen, 1987).

${ }^{8}$ A. Symons, The Fool of the World and Other Poems (London: Heinemann, 1906), pp. 79-80. 
I do not intend to discuss the poetic values of these verses here, but there are important features in them that characterise Symons's dance-pocms, and introduce the dances depicted by Yeats and Joyce. Bodily desire, covered countenance (for the dancers as well as the desires of the poet did not show their face), quickening speed of music and dance, a shudder that represents the sexual act, a sudden stop at the end and lurking, indirect references to death prefigure Yeats's The King of the Great Clock Tower or A Full Moon in March (1935) written more than thirty years later, just like the verse fragments about dancing witches that Joyce dedicated to this theme roughly about the same time Symons wrote the above poems.

The dancer's power over human fate and the lurking passion behind the surface of her ethereal face were favourite subjects of poets, painters and dramatists, apart from Yeats and Joyce. The account of the death of St. John the Baptist appears in the Gospels of Mark, 6:14-29, and Matthew, 14:1-12. Salome, the dancer, appears in these narratives as an innocent tool in her wicked mother's hands. Her fatal role, however, causes the death of the prophet, and that is why she has become inseparably connected with immoral, sensuous beauty. Her dance not only pleased but provoked Herod, the incestuous adulterer, so much so, that he promised to fulfil whatever she wished. Salome and her mother, Herodias, were sometimes confused or identified in literary works. Thus, she is made responsible for the murder not only 'aesthetically,' through her dance, but also morally.

According to Sylvia C. Ellis," the long line of artists who wrote about the Salome legend in the nineteenth century was opened by Heinrich Heine. His Atta Troll (1841) mentions Herodias, the mother, who, in Heine's version, was in love with the prophet, whose refusal provoked her hatred. In the poem she is one of the huntresses after the escaped dancing bear. Heine presents Herodias (and not Salome!) kissing the severed head of her victim, and Salome merely as her tool. Yeats and Joyce read Atta Troll, and its influence can be found in their writings: Yeats mentions it in his notes, when he compares Oscar Wilde's Salome with his own A Full Moon in March, and Joyce refers to it in the Notesheets of Ulysses. Mallarmé and Flaubert also wrote versions of the story. Mallarmé's "Hérodiade,"10 in which Hérodiade is identified with Salome, was published in 1866, but the poet did not complete it to his own satisfaction until just before his death in 1898 . He describes a cold, virginal beauty, Artifice itself, whose

\footnotetext{
"Jillis pp.1-85.

10 It was Arthur Symons, who translated Mallarmé's "Hérodiade" and published it in The Saroy in December, 1906.
} 
feelings are awakened by the prophet's glance and only the death of John the Baptist can satisfy her for this "intrusion." When John's severed head is brought to her, she dances with it and kisses its lips, then places it on her thighs. The blood stains her skin. This is her second dance; the first, the "dance of the seven veils" was performed before Herod with the purpose of obtaining her victim's head. These details are important in reference to Yeats's plays, who borrowed elements from Mallarmé, for example, the bloodstains on the Queen's skin and dress.

1877 saw the publication of Flaubert's "Hérodias." His heroine is an irresponsible, naive child. She is completely unaware of her powers as a dancer. She suggests a contrast with Mallarmé's Hérodiade. Yet either cold and virginal, or childish, these dancers are transformed during their dance. The icy, queenly idol warms up; her cruelty being satisfied by blood, her nascent and oppressed sexuality reveals itself. The childlike girl appears as a sensuous woman. Both seem to be unaware of the change the dance has brought into their lives. Flaubert describes the dance of his Hérodias in minute detail, and emphasises its eroticism, contrasting her innocence and ignorance.

Oscar Wilde's play Salome (1893) and Arthur Symons's poem "The Dance of the Daughters of Herodias" (1897) ${ }^{11}$ also deserve our attention. Wilde's Salome follows the example of Maliarmé's heroine: her rejected love finds revenge and satisfaction only in the death of the offender. Salome, however, is neither cold nor childlike: she is full of passion and desire even when she is not dancing. There is no instruction from her wicked mother, she is fully conscious of the effects of her dance and responsible for its consequences. Her demand for the head of her victim terrifies the king, her perversity in kissing and dancing with the trophy disgusts him. Consequently, Herod orders his soldiers to crush her to death with their shields. In Yeats's play, A King of the Great Clock Tower, the King of Time also makes an attempt to kill the Queen and strike at the head, but the dancing Qucen seems to be protected by a mysterious aura, which stops him.

Symons's poem ${ }^{12}$ returns to the innocent girl in Flatibert's "Hérodias." Salome is described as a young and beautiful tree, awakened to ciance by the wind. She and the

\footnotetext{
"It is a pity that Ellis ignores those poems by Symons which I include here, that is, "To a Gitana Dancing" and "The Armenian Dancer," because they are just as important as "The Dance of the Daughters of Herodias," since they also describe powerful Salome-figures, although without declaring them so.

12 "Here is Salome. She is a young tree / Swaying in the wind, her arms are slender brancires, / And the heavy summer leafage of her hair / Stirs as if rusting in a silent wind; / Her narrow feet are rooted in the ground, / But when the dim wind passes over her, / Rustlingly she awakens, as if life / Thrilled in lier body to its finger tips. .. / They dance, the daughters of Herodias, / With their eternal, white, unfaltering feet, / And always, when they dance, for their delight, / Always a man's head falls because of them. / Yet they
} 
other "daughters of Herodias" dance only for their own delight. They are not the scheming, obsessed avengers of Mallarmé or Wilde; but "when they dance, ... Always a man's head falls because of them." They are "the eternal enemy" - the enemy of men, femmes fatales. In one of Joyce's epiphanies, which I will discuss briefly in the second half of this essay, the dancing, whirling youth resembles these unselfconscious dancers. In my opinion, Joyce was aware of the resemblance, so he was at pains to point out that in the epiphany it was "not the dance of the daughters of Herodias" and it was "male."

In my view, Symons's poem suggests an antagonistic conflict in the feminine nature, which characterises the attitude of many artists towards the figure of the dancer. In this poem Salome is multiplied and eternalised; she has become the symbol of the fatal woman, who is hardly aware of the consequences of her powers as a dancer and a woman. She is only conscious of two things: dancing for her own delight and desiring the love of men. The previous interpretations of the figure of Salome presented her, in one way or another, as a whore: an irresponsible, immature, childish character, or a cold, selfish, unsatisfied person, who is obsessed by revenge, or a passionate woman, who is governed entirely by her love and hatred. Symons presents a different Salome. She does not dance because she wants to achieve her purposes, or because she was instructed to do so, or in her passionate love, or to celebrate her victory and possession of her victim's head; it is her own delight that inspires her into dance - "she dances for her own delight," as Symons writes about Jane Avril, the famous dancer in his poem "T.a Melinite: Moulin Rouge."13 This is the most dangerous kind among the dancers, as compared to literary predecessors, who always had a reason more or less logical to the human (that is, male) mind. The self-sufficiency of Symons's Salome has achieved a high degree when it kills men. The fatal effects of her dance anticipate the dance of the Hawk-Woman in Yeats's play At the Hawk's Well (1916), which mesmerises Cuchulain it is the dance that forces him to follow her, a dance of seduction. The Hawk's magical glance, which dooms the hero to kill his own son in On Baile's Strand (1904), is only a consequence of the enticing dance, that first takes hold of him.

If we consider Yeats's poems and prose works that could have been influenced by Symons's "The Dance of the Daughters of Herodias," we can find many examples, three of which I will discuss here. In 1899 The Wind Among the Reeds was published. It contains, among other poems, "The Hosting of the Sidhe." I suggest that the following

desire not death, they would not slay / Body or soul, no, not to do them pleasure: / They desire love and the desire of men; / And they are the eternal enemy." in Arthur Symons, Poems (London: Martin Secker, 1924), vol. 2, p. 36.

${ }^{13}$ Symons, Poems, Vol. 1, p. 190-1. 
lines indicate a correspondence between Symons's poem, Yeats's play mentioned above, and the biblical figure, Salome: "And if any gaze on our rushing band, / We come between him and the deed of his hand." Herod saw Salome dancing and, as a consequence, he was forced to fulfil her wish and behead John the Baptist. Cuchulain saw the Guardian of the Well dancing, and had to leave the well of immortality without tasting its water, with the curse of her glance on him. A man's head falls, whenever a daughter of Ierodias is seen dancing. As Yeats's comments on this poem show, the Sidhe, apart from being an evil faery, is

also Gaelic for wind, and ccrtainly the Sidhe have much to do with the wind. They journey in whirling winds, the winds that were called the dance of the daughters of Herodias in the Middle Ages, Herodias doubtless taking the place of some old goddess. When the country people see the leaves whirling on the road they bless themselves, because they believe the Sidhe to be passing by. [...] [T] he great among them, for they have great and simple, go much upon horseback. If anyone becomes too much interested in them, and sees them over much, he loses all interest in ordinary things. ${ }^{\text {If }}$

The associations of the daughters of Ilerodias with the Sidhe and their dance with the whirlwind derive from Jacob Grimm's Teutonic Mythology. ${ }^{15}$ Grimm picks up the thread of the Salome legend where the above plavs and poems drop it. He describes how, when Salome attempts to kiss the lips of the severed head of the Precursor, they begin to blow, and their wind whirls her into space. Therefore the whirlwind is associated with the "gyrating dancing of Herodias." The Celtic tradition holds the Sidhe responsible for the stirring of the whirlwind.

In "Nineteen Hundred and Nineteen" the image of the dancing daughters of Herodias returns. Section VI of the poem appears to be a direct continuation of Symons's poem as well as of "The Hosting of the Sidhe":

Violence upon the roads: violence of horses;

Some few have handsome riders, are garlanded

On delicate sensitive ear or tossing mane

But wearied running round and round in their courses

All break and vanish, and evil gathers head:

14 The Variorum Edition of the Poems of W. B. Yeats, eds. Peter Allt \& Russel K. Alspach (New York: Macmillan, 1957), p. 800.

${ }^{15}$ Jacob Grimm, Teutonic Mythology (London: Gicorge Bell \& Sons, 1882), Vol. 4, p. 285. 


\begin{abstract}
Herodias' daughters have returned again, A sudden blast of dusty wind and after Thunder of feet, tumult of images, Their purpose in the labyrinth of the wind; And should some crazy hand touch a daughter All turn with amorous cries, or angry cries, According to the wind, for all are blind. ${ }^{16}$
\end{abstract}

The approaching threat of troubles in Ireland is presented in this powerful metaphor of the whirlwind. The synecdoche, "crazy hand" that dares "touch a daughter," refers to the enchanted men, who see the Sidhe dancing. Their fate is predicted in the "amorous," or "angry cries": the daughters of Herodias desire the love of men, yet these men are to part with their heads. The new element is the blindness of the daughters. In my opinion, it suggests a twofold meaning: the blinding "sudden blast of dusty wind," which covers their eyes as well as the eyes of humans who look at them (reminding the reader of the veiled dancer or her covered countenance of Mallarmé's "Hérodiade" or Symons's "The Armenian Dancer"), and the whirl of the dance, which goes "round and round" without letting anybody or anything disturb its course. The interference of the "crazy hand" attempts to break it: it is inevitable that the dancers turn on the intruder, either to satisfy their desire or to punish his insolence.

The impression Yeats gives us in his commentary on Salome in A Vision is different from the previous interpretations:

When I think of the moment before revelation I think of Salome ... dancing before Herod and receiving the Prophet's head in her indifferent hands, and wonder if what seems to us decadence was not in reality the exaltation of the muscular flesh and of civilisation perfectly achieved. ${ }^{17}$

In this context Salome appears the closest to a priestess, who takes part in a ritualistic dance, prepares the sacrifice, and thus achieves what Yeats calls "revelation," the union of the primary and the antithetical, physical and spiritual, Phase Fifteen, the Phase of the Dancer. She is indifferent: she does not want the death of St. John the Baptist for personal reasons, only takes it as a necessary and inevitable event which would promote a higher goal.

${ }^{16}$ N. A. Jeffares, ed., Yeats's Poems (London, Macmillan, 1989), p. 317

17 W. B. Yeats, A V ision (I iondon: Macmillan, 1925; 1937), Version 'A' p. 273, 'B' p. 185, emphasis mine. 
The dancer as femme fatale appears in a different setting from Salome's myth in Rosa Alchemica (1897), but with a similar vocation. Michael Robartes, initiating his friend, Owen Aherne, the narrator, to the rites of his mysterious sect, leads him into a hall, where there are men and women "dancing slowly in crimson robes." The narrator, weary of the dance, sinks into a half-dream, in which he sees the petals of the great rose on the ceiling "falling... and shaping into the likeness of living beings," which begin to dance. "... a mysterious wave of passion, that seemed like the soul of the dance moving within our souls, took hold of me and I was ... swept into the midst" (my emphasis). His dance-partner, suddenly appearing in front of him, is a beautiful "immortal august woman", one of the former petals of the rose. She fills him "with a great horror that I danced with one who was more or less than human, and who was drinking up my soul... and I fell and darkness passed over me" (my emphasis). The transcendental force that sweeps him into the middle of the dance is like the whirlwind in the previously mentioned poems, while the loss of the narrator's soul signifies spiritual decapitation, and the ritualistic dance that precedes it recalls the above passage about Salome preparing the revelation, the Unity of Being, as Yeats would have called it twenty years later - the secret of Rosa Alchemica.

Two of Yeats's dance-plays, generally known among the critics as his 'Salomeplays,' are versions on the same theme. The King of the Great Clock Tower and A Full Moon in March (1935) present an almost identical plot: a Swineherd/Stroller arrives to woo the Queen, he is beheaded, the Queen dances before his head, kisses its lips, and the head starts singing. The second play is a rewritten version of the first; Yeats realised that there was one character too many, and left the King out. In every respect the latter play is more perfect and concise: it underlines the contrast between the two main characters and in the Queen's turbulent emotions. Nevertheless, the first play renders the Queen's dance more central, and the whole play shows more affinity with it, whereas in the second version the dance is the catalyst of the union between the Queen and the Swineherd, a means and not a goal in the structure of the play. The King of the Great Clock Tower ${ }^{18}$ starts and ends with the Attendants' talk about dancers and dancing. Although these references are a bit artificial, and the second play offers better solutions, artificiality is not irrelevant here: the distant Queen, "Dumb as an image made of wood or metal, / $A$ screen between the living and the dead" and the bold, "sacred" Stroller are symbolic and unearthly. The other play emphasises sexual attraction and spiritual hatred, which have no such significance in the first.

${ }^{18}$ Yeats dedicated this play to Ninette de Valois, the famous baller dancer, who danced the Queen. 
For Yeats there was a practical reason for the King's presence in the first play: Ninette de Valois, who danced in the Queen's role in the first play, was not trained as an actress and could not speak lines, therefore the Queen had to remain silent and it was necessary to create another character. In the second play the Queen is replaced by a dancer as she is about to dance. Yeats, being familiar with the renditions of the theme, especially Mallarmé's "Hérodiade," realising, however, that his presentation of the Queen's dance is very close to that of Oscar Wilde's Salome, pointed out in his Notes on A Full Moon in March:

The dance with the severed head suggests the central idea in Wilde's Salome. Wilde took it from Heine [Atta Trol], who has somewhere described Salome in Hell throwing into the air the head of John the Baptist. Heine may have found it in some Jewish religious legend, for it is part of the old ritual of the year: the mother goddess and the slain god. In the first edition of The Secret Rose there is a story based on some old Gaelic legend. A man swears to sing a woman's praise: his head is cut off and the head sings. In attempting to put this story into a dance play I found that I had gone close to Salome's dance in Wilde's play. But in his play the dance is before the head is cut off. ${ }^{19}$

In my opinion, the main difference Yeats refers to in the last sentence of the above quotation is that the dance occurs as an acknowledgement and return of the Swineherd/Stroller's love. The roles are changed: the wooer (Wilde's Salome) becomes the wooed (Yeats's Queen). Although Yeats does not mention Mallarmé in this quotation, he knew the French poet's "Hérodiade" through Symons's translation, as he refers to it in his essay "The Tragic Generation" in 1910. In that version the princess performs two dances: one before Herod, which is the dance of the seducer in seven veils; the other dance takes place after the prophet's head has been brought to her, and closely resembles the Queen's dance in Yeats's play. The new element is the Stroller's prophecy, which predicts that his severed head will sing and the Queen will dance before it. The Queen's kiss and dance are the reward for the man who sings his love and passion for her best. In The King of the Great Clock Tower the Stroller arrives without any previous notice or call from the silent, impassive Queen - Yeats's other Queen makes a competition for her wooers. In the first play it is the rightful anger and jealousy of the King that leads to the Stroller's death, in the second the Queen, in a moment of caprice, orders the Swineherd's decapitation - it is not his passion she

1. The Variorzm Edition of the Plays of W. B. Yeats, eds. l'eter Allt and Russell K. Alspach (London: Macmillan, 1966), p.1311. 
punishes and rejects but his insolence and foul appearance. Both plays are set at a special moment of the year. The Swineherd arrives to woo and aims to wed the Queen at the full moon in March. The Stroller comes on New Year's Eve and the silent Queen dances and kisses his severed head at the stroke of midnight when the old year dies and the new one starts. Symbolically, it refers to the death of her love for the King and the appearance of his successor in her feelings and passion. Yeats suggests that this new relationship is stronger than the old because the Queen sings after the Stroller is taken to be executed, although she did not utter a word to the King for a whole year. The Queen is offered a choice: she can save the Stroller if she speaks. As she does not open her mouth then, it becomes obvious that the Stroller must die so that the prophecy could be fulfilled. In both plays the Queen appears first as an almost bodiless, cruel, cold, inhuman being. Her suitor's words, on the contrary, reveal a coarse, sensuous, self-sufficient man; it is only his extreme confidence in his own prophecy that distinguishes him. The undertones of sexual attraction in the play are poised against the spiritual hatred the Queen proclaims and the scorn the Stwineherd hides in his wooing. In Yeats's special theory of subjective and objective men, the Queen is the emblem of subjectivity; she rejects any attempt to break her solitude, yet she challenges all men to save her from the rigid control over herself. The Swineherd is her male counterpart, matching her in subjectivity, solitude and independence. His wooing is unlike the traditional pattern of courtly love left to us by minstrels and chivalrous poetry. The spiritual hatred embedded in sexual love that Yeats, after William Blake, described in many poems (for example, "Crazy Jane Looks at the Dancers"), and particularly in $A$ Full Moon in March, is based on the identical disposition of the lovers. They cannot complement each other: their similarity of nature is acknowledged but not tolerated. At the same time they represent opposite social positions and values - in the two Attendants' introductory song the "crown of gold" and "dung of swine" are reconciled by the power of love. After the Swineherd's head is taken, the change in their roles culminates in the Queen's dance. The head sings of Jill who murdered Jack and hung his heart on the sky; the song is an absurd but precise summary of the play. The Queen, who caused her wooer's death, dances with his severed head - in a sense accepts him to be her 'lover.' The ritualistic sacrifice appears in the Head's song and it parallels the plot of the play; the song, the artefact, can be created only by sacrificing the artist. Her awakened sexuality acknowledges the truth of his prophecy; the Head sings of the world of the dead, who, though lacking flesh and blood, are morc alive than the living. In her cradle-song the Queen tries to compensate the head for her cruelty or caprice and also to refuse her responsibility in his death. Regarding herself as 
the cause of his death, however, cannot be avoided and her reaction to the charge of murder is a laughter which is crazy perhaps, but it merely echoes the Head's. She places the trophy on the throne and dances before it, "alluring and refusing," then "in adoration." The control has disappeared from her nature, she is full of passion. She kisses the dead lips of the Head and cradles it on her breast. Her gestures suggest sexual as well as maternal love, perhaps indirectly referring to the Swineherd's story about a drop of blood impregnating a woman (the Queen's blood-stained costume also indicates that) and her unity with the Swineherd in love - they are not separate beings any longer, but one body and one spirit. She dances with the head in her hand quicker and quicker to drum-taps, and as the dance approaches its climax, she kisses the head. She stops dancing but her body shivers as she stands to very rapid drum-taps. Then the sounds cease and she sinks down with the head. The dancer, being now complete, collapses into herself. This way of ending the dance Yeats develops to perfection in his last play, The Death of Cuchulain.

In The King of the Great Clock Tower the head sings about the famous, tragic heroes of Ireland, who ride again "Out of Ben Bulben and Knockarea" (1. 169) and haunt the world. They return from the grave, because, as the song explains, their world lacks "Their desecration and the lover's night." In both plays the Queen kisses the lips of the severed head. It symbolises the union between the living woman and the spirit of the dead man and occurs as a conclusion of the dance. Spirit and body arc united in this kiss and thus Unity of Being is achieved, and eternally maintained - the King of Time is unable to strike at them, as he attempts to do in The King of ithe Great Clock. Tonver and the Queen is relcased from her sclf-control, achieving her "desecration and the lover's night" at the full moon. The beheading - the sacrifice - has 'bencificial' consequences on both characters: the cold Queen becomes a living woman, and the Swineherd/Stroller's head becomes capable of singing.

Although The King of the Great Clock Toiver is the earlier play which was practically rewritten later, it nevertheless concentrates more on the dance, while the second play renders passion, cruelty and love central. First of all, as Yeats's stage directions go: "When the stage curtain rises it shows an inner curtain whereon is perhaps a stencilled pattern of dancers." The two Attendants, who introduce the play, talk about dancing faeries, referring to this pattern: 
SECOND ATTIENDANT: They dance all day that dance in "Tir-nan-oge. FIRST ATTIENDANT: There every lover is a happy rogue;

And should he speak, it is the speech of birds.

No thought has he, and therefore bas no words,

No thought because no clock, no clock because

If I consider deeply, lad and lass,

Nerve touching nerve upon that happy ground,

Are bobbins where all time is bound and wound.

[my emphases]

What is the role of dancing faeries and all the Attendants' strange talk about "that happy ground"? Considering, that nobody in the play seems to know where the Queen has come from, secondly, that her silence is similar to that of the wordless lovers in the song quoted above, finally, as she dances for love at the end of the play, I assume that she is of the faery kind herself, unlike the other Queen, who is a proud virgin woman. In $A$ Full Moon in March the Attendants are busy dividing the roles among themselves - there is no word about dancing till the Queen actually starts performing. Similarly, at the end of the play the song of the Head is about passion and murder, whereas the earlier play closes with the First Attendant remembering

Castle Dargan's ruin all lit, J.ovely ladies dancing in it.

and, as the other Attendant points out that they must have been dead, he confirms his vision:

Yet all the lovely things that were

Live, for I saw them dancing there.

As the Stroller claims to be a sacred man, a poet or a fool, whose transcendental connections are well-known, and the mute Queen is, as I suppose, an otherworldly creature, their mysterious union is not so much the reconciliation of antinomies as it is in the second play, but the meeting of kindred spirits, who are not bound by time, therefore the King cannot strike at them. 
The Salome legend was also known to the young James Joyce. He was familiar with Heine's Atta Troll, and mentioned it in the Notesheets of Ulysses. ${ }^{20} \mathrm{He}$ claimed to know by heart everything that Flaubert had written, and he certainly read "Hérodias." 21 He was also familiar with Symons's poem, the title of which he quoted in one of his epiphanies, as well as with Wilde's Salome. Although Joyce could not have seen Salome as it was staged only in Paris in 1896 and in Germany in 1901, it was famous due to the scandals it caused. Joyce probably knew some other renditions of the theme, too; there were many more in the early nineties. He refers to it in one of the epiphanies recorded in 1902, shortly after the death of one of his brothers, Georgie. In this epiphany ${ }^{22}$ Joyce relates a dream, in which he saw his dead brother dancing. Stanislaus Joyce also records the death and the epiphany in My Brother's Keeper. ${ }^{23}$ The dead boy dances in an amphitheatre before the multitude. His dancing body whirls up to space and falls back again to the earth. I suggest that the dream combines the image of the young King David, who danced and played his lute before his people and thus went to Jerusalem after a victory, and Blake's vision of his dead brother clapping hands and rising up to Heaven; Joyce, who was educated by Jesuits, would have known the Bible very well, and Stanislaus Joyce notes that "His gods were Dante and Blake." 24 Joyce emphasises the unique dance of his brother: he dances without music, his movements are "slow and supple." He "seems to be a whirling body, a spider wheeling amid space, a star... His dancing is not the dancing of barlots, the dance of the daughters of Herodias. It goes up from the midst of the people, sudden and young and male, and falls again to earth in tremulous sobbing to die upon its triumph" (my emphasis). If we recall Grimm's account of how John the Baptist blew Salome into space where she had to whirl forever, we can see how carefully Joyce makes a difference between the two dances: such expressions as "whirling body," or "wheeling amid space" connect them, but the motif of Eros is missing from Georgie's dance; it is evident, that it is "not the dance of the daughters of Herodias." It is worth noting that the focus of attention moves from the boy to his dance: it acquires a life of its own, it is "sudden and young and male," it "sobs" and "dies": these details all describe Georgie, yet refer to the dance, as if the boy has

\footnotetext{
20 Joyce's Ubysses Notesheets in the British Museum, "Circe" 4. Eid. Philip F. Herring (Charlottesville: Virginia UP, 1972), p. 286.

${ }^{21}$ Richard Ellmann, James Joyce (Oxford: OUP, 1959), p. 506.

22 Robert Scholes and Richard M. Kain, The Workshop of Stephen Dedalys. James Joyce and the Ran Materials for A Portrait of the Artist as a Young Man, (Evanston, Illinois: Northwestern UP, 1965), p. 33.

${ }^{23}$ Stanislaus Joyce, My Brother's Keeper (london: Faber \& Faber, 1958), p. 136.

${ }^{2+}$ Stanislaus Joyce, p. 53.
} 
become identified with the dance himself. It is also important that the whirling, wheeling movement is emphasised. The association of the dancer with the whirlwind is present in the writings of both Yeats and Joyce. The wheeling, circling dance belongs to the complex of the gyrating progress of history, emerging as the Romantic image of the world (although it can be found in medieval paintings as well) and influencing later styles, such as Impressionism and Expressionism; enough to think of Shelley's poem "Ode to the West Wind" and Turner's many pictures depicting storms and whirlwinds, or Kokoschka's Whirlwind (1914). ${ }^{25}$

The motif of the severed head and the femme fatale dancer appear in Ulysses, too. In the Notesheets ${ }^{26}$ of the Circe episode Joyce inserted a curious note which he later crossed out: "severed head speaks." Interestingly, there is a female severed head mentioned in the final text, which Bloom's alter ego, Henry Flower, caresses on his breast. On the same page (525) in another hallucination, Bloom's grandfather, Lipoti Virag, unscrews his own head and holds it under his arm. The head says "Quack!", indicating bird sounds, and "exeunts severally." I suggest that the latter word is not accidental: it refers to the motif of the severed head. It is likely that Joyce intended to mock the esoteric beliefs of Yeats and $Æ$ (George Russell) about the soul taking the shape of a bird after death. But why is the head, which Henry holds, female? Furthermore, Henry Flower does not dance at all! In order to find the key to this enigma, we have to note that Henry Flower is Bloom himself, one imagined and idealised side of his personality, that takes shape in his hallucination. Furthermore, at first Bloom becomes a swine, then obtains female characteristics: Bella Cohen, the powerful whoremistress turns into a man, Bello, and changes Bloom into Ruby Cohen, "a charming subrette." The change of sex and sexual behaviour provides the basis for the severed head being female; it most probably indicates Bloom's head, as a metaphoric anticipation of his dehumanisation and loss of masculinity. The unacknowledged fear of emasculation by a woman, allegedly present in every man's subconscious according to Freudian psychologists, is brought to the surface in his hallucination and the dramatisation of the events (both real and imaginary) suggest that we are in fact witnessing an erotic day-dream ${ }^{27}$ in which the scary and the desirable blend into one, as the masochistic features in Bloom's personality get disclosed. As

\footnotetext{
${ }_{25}$ Péter Ligri,. Value and Form. Comparative Literature, Painting and Music. (Budapest: Nemzeti Tankönyvkiadó, 1993), p. 166.

${ }^{26}$ Joyce's Ulysses Notesheets p. 313.

${ }^{27}$ In fact this day-dream is delayed by two chapters, as Bloom masturbated in the Nausicaa episode, but we have no information whether he was day-dreaming then or not.
} 
Henry Flower, he loses his head and as Bloom, he loses his 'flower': his masculinity. Experiencing the (imagined) fate of a woman, which has awakened his curiosity so many times that day, gives him a strange kind of satisfaction. The man-tamer BellaBello proves to be fatal indeed, rather a virago fatale, than femme. Insofar as the whores and Bella, like "the daughters of Herodias," are all 'Salomes,' the motif of the seductive dance should not be missing, either. It occurs later, not in front of the severed head, although in the Notesheets there is a sentence that shows Joyce's probable intention to include the dance, before the motif of the severed head appears: "whores dance around I.B [Leopold Bloom]." However, Joyce changed it in the final version: Bloom stands aside, and joins the dance only later to turn with Bella, while Stephen is the one who is danced around. After a series of the humiliating hallucinations he suffers as a female, Bloom breaks the spell and regains his original sex, casting off Bella's influence. They waltz together, united as a hermaphrodite: "Bloombella." This is not an erotic, exciting dance with veils: this is a sweaty, clumsy, drunken hopping around, a caricature of seduction. Nevertheless, it ends, in a sense, with the invocation of the spiritual world, but it is not the magical power of the whores' dance. Stephen separates himself from them and dances tripudium alone. He cries out: "Dance of death." This sentence already points forward, to the vision of Stephen's dead mother, but it also closes the dance-scene. Thus, we have the motifs of the severed head, the dance, and death, although in reversed order if compared to other renditions of the Salome legend.

Finally, Finnegans Wake is also a 'lucky dip' for the Salome legend. If we consider the whole book in general, the hints of incest in the relationship of H.C.F. and his daughter, Issy, mirror Herod's lust for his provocative stepdaughter. The fact that Joyce was not satisfied with only one Salome suggests that Joyce discovered and incorporated his daughter's developing mental illness in the Wake. He wanted two, corresponding to Issy and her "linkingclass" (looking-glass, after Lewis Carroll) sister. lucia Joyce's schizophrenia developed roughly at the same time as Joyce started to write his drafts and sketches for the book. It may be noteworthy that she was in fact a trained dancer. She was fourteen when Ulysses was published, and the first signs of her split personality appeared in the early 20 s, as Joyce's letters and notes show. The two "salaames" 28 are the manifestations of H.C.F..'s daughter(s) as well as the two girls whom he spied on in the park: indirectly, they caused his fall. In Book III, Chapter 3 they join the keening procession around the bulk of Yawn-Shaun (and within him H.C.E.), as well as the mourning dance that follows it, "tripping a trepas." ${ }^{29}$ In the

\footnotetext{
${ }^{2 \kappa}$ James Joyce, Finnegans IV ake (l.ondon: Faber \& Faber, 1939), 493.32

29) James Joyce 499
} 
"Scribbledehobble" notebook Joyce inserted the word "tetracha" into this passage, a reference to Herod, tetrarch and Salome's stepfather, as well as Ezra Pound's "Our Tetrarchal Précieuse," 30 - Joyce did not include this in the published version, but this does not mean that the dancer would not have strongly held his imagination: this final instance in fact shows just how deeply the motif here explored concerned the writers of the era.

30 David Hayman, The "Wake" in Transit (Ithaca: Cornell UP, 1990), pp. 62, 88, 89, 90. Hayman claims that Joyce's Isolde is based on Jules Laforgue's "Salome," the translation of which by Ezra Pound was also known to him. 